Journal of Epidemiology and Public Health (2018), 3(2): 118-127

https://doi.org/10.26911/jepublichealth.2018.03.02.02

\title{
Risk Factors of Breast Cancer in Women at Dr. Moewardi Hospital, Surakarta, Central Java
}

\author{
Yana Listyawardhani'), Ambar Mudigdo²), Rita Benya Adriani3) \\ 1)Masters Program in Public Health, Universitas Sebelas Maret \\ 2)Faculty Teaching and Educational Sciences, Universitas Sebelas Maret \\ 3)Diploma Program in Speech Therapy, School of Health Politechnics Surakarta
}

\begin{abstract}
Background: Breast cancer is a leading type of cancer affecting women around the world. Its incidence is increasing in developed and developing countries. Breast cancer is the leading cause of death among women in Indonesia with 19,731 cases of death in 2014. In addition to mortality, breast cancer causes psychosocial effect in the affected and the family. This study aimed to determine the risk factors of breast cancer in women at Dr. Moewardi Hospital, Surakarta, Central Java.

Subjects and Method: This was an analytical observational study with case control design. The study was conducted at Dr. Moewardi Hospital, Surakarta, from October to December, 2017. A total sample of 200 study subjects consisting of 100 women with breast cancer and 100 women without breast cancer were selected for this study by fixed disease sampling. The dependent variable was breast cancer. The independent variables were age at menarche, age at first pregnancy, parity, duration of breastfeeding, use of fertility hormone, duration of hormonal contraceptive use, and age at menopause. The data was collected by questionnaire and analyzed by multiple logistic regression.

Results: The risk of breast cancer increased with earlier age at menarche $<12$ years old $(\mathrm{OR}=2.71$; $95 \% \mathrm{CI}=1.06$ to $6.96 ; \mathrm{p}=0.037)$, delayed age at first pregnancy $\geq 30$ years old $(\mathrm{OR}=3.01 ; 95 \% \mathrm{CI}=$ 1.16 to $7.78 ; \mathrm{p}=0.023)$, delayed age at menopause $\geq 55$ years old $(\mathrm{OR}=1.07 ; 95 \% \mathrm{CI}=0.82$ to 6.30 ; $\mathrm{p}=0.001)$, longer hormonal contraceptive use $\geq 10$ years $(\mathrm{OR}=3.25 ; 95 \% \mathrm{CI}=1.20$ to $9.63 \mathrm{p}=$ 0.003).
\end{abstract}

Conclusion: The risk of breast cancer increases with earlier age at menarche, delayed age at first pregnancy, delayed age at menopause, longer hormonal contraceptive use.

Keyword: breast cancer, risk factor

\section{Correspondence:}

Yana Listyawardhani. Masters Program in Public Health, Universitas Sebelas Maret, Jl. Ir. Sutami 36 A, Surakarta 57126, Central Java. Email:yanalistya@gmail.com

\section{BACKGROUND}

Current disease patterns are shifting from infectious diseases and nutritional problems to degenerative diseases including breast cancer (In Sibio et al., 2016).

Breast cancer affects many women in the world. Breast cancer is characterized by uncontrolled or malignant growth of breast epithelial tissues (Lukong, 2017). Its incidence increases in developed and developing countries. Breast cancer accounts for $29 \%$ of all new cancers and $14 \%$ of all cancer deaths in women worldwide in 2012. There were reported 1.7 million new cases of breast cancer with 522,000 deaths in 2012 (Leon et al., 2017). The incidence of breast cancer in developed countries in 2012 was as many as 793,700 cases. The incidence rate of breast cancer is higher than colon, rectum, lung, bronchial, and tracheal cancers (World Health Organization, 2014; Ministry of Health RI Center for Health Data and Information, 2015; Kweon et al., 2017). 
In developed countries, the number of deaths from breast cancer amounted to 197,600 deaths. This breast cancer specific death rate was lower than that in the developing countries. For example, in the United States by 2015 there were 231,840 new cases and 40,290 deaths due to breast cancer (Di Sibio et al., 2016).

In Southeast Asia, the incidence rate of breast cancer was $27 \%$ of all cancers in women. Breast cancer mortality rate was $18 \%$ of all deaths from breast cancer (Graham et al., 2016).

In Indonesia, the incidence of breast cancer was 48,998 cases with 19,731 deaths (Ministry of Health RI Center for Data and Health Information, 2015). In 2013, the highest prevalence of breast cancer occurred in Yogyakarta Province, which was $4.1 \%$. This figure was higher than the national rate of $1.4 \%$. The highest prevalence of breast cancer occurred in Central Java and Bali, ie 2.1\% and 2.0\% (Ministry of Health RI Center for Data and Information Health, 2016).

To the extent of the author's knowledge, studies on the risk factors of breast cancer using multiple regression analysis in Indonesia are sparse. Based on the background, the author were interested to examine the risk factors of breast cancer in women at Dr. Moewardi Hospital, Surakarta.

\section{SUBJECTS AND METHOD \\ 1. Study design \\ This was an analytic observational study with a case control design. The study was conducted at Mawar III ward, Dr. Moewardi Hospital, Surakarta, Central Java, Indonesia, from October to December 2017.}

\section{Population and sample}

A sample of 200 study subjects was selected for this study by fixed disease sampling, consisting of 100 breast cancer patients and 100 non breast cancer in-patients in Mawar ward, Dr. Moewardi hospital, Surakarta with $1: 1$ ratio.

The exclusion criteria were inpatients who had complication disease or had psychiatric disorder, unable to read or write.

\section{Study variables}

The dependent variable was breast cancer. The independent variables were age at menarche, age at first pregnancy, parity, duration of breastfeeding, use of fertility hormone, duration of hormonal contraceptive use, and age at menopause.

\section{Operational definition of variables}

Breast cancer was defined as an abnormal growth of abnormal breast tissue with excessive growth, no coordination with normal tissue growth, grows infiltratively and destructively, and may metastasize and will continue to grow. The data of breast cancer cases and non breast cancer control were taken from the medical record. The measurement scale was categorical, coded o for non breast cancer and 1 for breast cancer.

Age at menarche was defined as the maternal age (year) at the first menstrual cycle. The data were collected by questionnaire. The measurement scale was continuous, but for the purpose of analysis transform into dichotomous, coded o for $\geq 12$ years old and 1 for $<12$ years old.

Age at first pregnancy was defined as maternal age (year) at the first pregnancy. The data were collected by questionnaire. The measurement scale was continuous, but for the purpose of analysis transform into dichotomous, coded o for $<30$ years old and 1 for $\geq 30$ years old.

Parity was defined as the number of children who had been born. The data were collected by questionnaire. The measurement scale was continuous. 
Journal of Epidemiology and Public Health (2018), 3(2): 118-127

https://doi.org/10.26911/jepublichealth.2018.03.02.02

Birth spacing was defined as the time interval (year) from previous child birth until the current pregnancy. The data were collected by questionnaire. The measurement scale was continuous.

Length of contraceptive use was defined as the duration (year) of delaying or regulating the number of pregnancies using artificial hormones. The data were collected by questionnaire. The measurement scale was continuous, but for the purpose of analysis transform into dichotomous, coded 0 for $<10$ years and 1 for $\geq 10$ years.

\section{Data analysis}

The sample characteristics were described in frequency, mean, standard deviation, minimum, and maximum, for continuous data. The sample characteristics were described in frequency and percent, for categorical data. The bivariate analysis involving categorical data was run by cross tabulation with odds ratio as the measure of the association and Chi square as the statistical test. The multivariate analysis employed a multiple logistic regression.

\section{Research Ethics}

The research ethical clearance was granted from the Research Ethics Committee at Dr. Moewardi Hospital, Surakarta, Central Java, Indonesia. Research ethics included issues such as informed consent, anonymity, confidentiality, and ethical clearance.

\section{RESULTS}

\section{Univariate analysis}

Table 1 shows the descriptive characteristics of the sample consisting of 200 study subjects. Most of the study subjects aged 50-59 years (36.5\%). As many as $62.0 \%$ study subjects attained <Senior high school. A few subjects were diploma or graduate (15.5\%). One-third of the study subjects were housewives. Half of the study subjects had income $<$ Rp 1,00o,ooo.

Table 1. Sample characteristics of maternal age, education, and employment

\begin{tabular}{|c|c|c|}
\hline Characteristics & $\mathbf{n}$ & Percent (\%) \\
\hline \multicolumn{3}{|l|}{ Age group } \\
\hline 20-29 years & 2 & 1.0 \\
\hline 30-39 years & 20 & 10.0 \\
\hline 40-49 years & 64 & 32.0 \\
\hline 50-59 years & 73 & 36.5 \\
\hline $60-69$ years & 32 & 16.0 \\
\hline 70-79 years & 9 & 4.5 \\
\hline \multicolumn{3}{|l|}{ Education level } \\
\hline $\begin{array}{l}\text { Elementary school and junior high } \\
\text { school }\end{array}$ & 124 & 62.0 \\
\hline Senior high school & 45 & 22.5 \\
\hline Diploma or bachelor degree & 31 & 15.5 \\
\hline \multicolumn{3}{|l|}{ Employment } \\
\hline Farmer & 18 & 9.0 \\
\hline Laborer & 42 & 21.0 \\
\hline Working at house & 60 & 30.0 \\
\hline Civil servant & 14 & 14.0 \\
\hline Merchant & 14 & 7.0 \\
\hline Private employee & 13 & 13.0 \\
\hline Employee & 39 & 19.5 \\
\hline \multicolumn{3}{|l|}{ Income } \\
\hline$<\operatorname{Rp} 1,000,000$ & 104 & 52.0 \\
\hline $\operatorname{Rp} 1,000,000$ to $<\operatorname{Rp} 2,000,000$ & 42 & 21.0 \\
\hline $\mathrm{Rp} 2,000,001$ to $<\mathrm{Rp} 3,000,000$ & 25 & 12.5 \\
\hline $\mathrm{Rp} 3,000,001$ to $<\mathrm{Rp} 4,000,000$ & 18 & 9.0 \\
\hline$\geq \operatorname{Rp} 4,000,000$ & 11 & 5.5 \\
\hline
\end{tabular}




\section{Bivariate analysis}

Table 2 shows the results of bivariate analysis between breast cancer and age at menarche, age at menopause, parity, and duration of contraceptive use. As expected the results of these crude analyses suggest associations between breast cancer and age at menarche, age at menopause, parity, and duration of contraceptive use. For example, women with age at menarche $\geq 12$ years were 0.38 times less likely to have breast cancer than women with age at menarche $<12$ years. Similarly, women with hormonal contraceptive use $\geq 10$ years were 3.60 times more likely to have breast cancer than women with $<10$ years.

Table 2. Chi-Square test on the association between breast cancer and the age at menarche, the age at menopause, parity, and duration of contraceptive use

\begin{tabular}{|c|c|c|c|c|c|c|c|}
\hline \multirow{2}{*}{ Independent Variable } & \multicolumn{2}{|c|}{ Case } & \multicolumn{2}{|c|}{ Control } & \multirow{2}{*}{ OR } & \multirow{2}{*}{$95 \% \mathrm{CI}$} & \multirow[b]{2}{*}{$\mathbf{p}$} \\
\hline & $\mathbf{n}$ & $\%$ & $\mathbf{n}$ & $\%$ & & & \\
\hline Age at menarche & & & & & 0.38 & 0.21 to & 0.002 \\
\hline$<12$ years & 45 & 65.2 & 24 & 34.8 & & 0.70 & \\
\hline$\geq 12$ years & 55 & 42.0 & 76 & 38.0 & & & \\
\hline Age at menopause & & & & & 7.83 & 3.15 to & 0.001 \\
\hline$<55$ years & 20 & 40.0 & 30 & 60.0 & & 19.46 & \\
\hline$\geq 55$ years & 47 & 83.9 & 9 & 16.1 & & & \\
\hline Age at pregnancy & & & & & 0.49 & 0.28 to & 0.016 \\
\hline$\geq 30$ years & 53 & 59.6 & 36 & 40.4 & & 0.87 & \\
\hline$<30$ years & 47 & 42.3 & 64 & 57.7 & & & \\
\hline Parity & & & & & 1.64 & 1.10 to & 0.072 \\
\hline$<3$ & 48 & 54.2 & 39 & 45.8 & & 8.91 & \\
\hline$\geq 3$ & 52 & $45 \cdot 4$ & 61 & 54.6 & & & \\
\hline Hormonal contraceptive use & & & & & 3.60 & 2.01 to & 0.001 \\
\hline$<10$ years & 33 & 34.0 & 64 & 66.0 & & 6.46 & \\
\hline$\geq 10$ years & 67 & 65.0 & 36 & 35.0 & & & \\
\hline
\end{tabular}

Table 3. A multiple logistic regression analysis on the risk factors of breast cancer in women

\begin{tabular}{lccc}
\hline \multicolumn{1}{c}{ Independent variables } & OR & 95\% CI & p \\
\hline Age at menarche $<12$ years & 2.71 & 1.06 to 6.96 & 0.037 \\
Age at first pregnancy $\geq 30$ years & 3.01 & 1.16 to 7.78 & 0.023 \\
Age at menopause $<55$ years & 1.07 & 0.82 to 6.30 & 0.001 \\
Hormonal contraceptive use $\geq 10$ years & 3.25 & 1.20 to 9.63 & 0.003 \\
N Observed $=$ 200 & & & \\
-2 Log likelihood $=86.70$ & & & \\
Nagelkerke R Square $=81.4 \%$ & & & \\
\hline
\end{tabular}

\section{Multivariate analysis}

Table 3 shows the results of multiple logistic regression analysis on the risk factors of breast cancer in women. As expected, age at menarche was a moderate risk factor of breast cancer. Women with age at menarche $<12$ years were more likely to get breast cancer than age at menarche $\geq 12$ years $(\mathrm{OR}=2.71 ; 95 \% \mathrm{CI}=1.06$ to 6.96 ; $\mathrm{p}=0.037)$.

Age at first pregnancy was a strong risk factor of breast cancer. Women with age at first pregnancy $\geq 30$ years were more likely to get breast cancer than age at menarche $<30$ years $(\mathrm{OR}=3.01 ; 95 \% \mathrm{CI}=$ 1.16 to $7.78 ; p=0.023)$. 
Journal of Epidemiology and Public Health (2018), 3(2): 118-127

https://doi.org/10.26911/jepublichealth.2018.03.02.02

Age at menopause <55 years was a weak risk factor of breast cancer. Women with age at menopause <55 years were more likely to get breast cancer than age at menopause $\geq 55$ years $(\mathrm{OR}=1.07 ; 95 \% \mathrm{CI}=$ 0.82 to $6.30 ; \mathrm{p}=0.001)$.

Hormonal contraceptive use of $\geq 10$ years was a strong risk factor of breast cancer. Women with hormonal contraceptive use $\geq 10$ years were more likely to get breast cancer than women with hormonal contraceptive use <10 years $(\mathrm{OR}=3.25 ; 95 \% \mathrm{CI}=1.20$ to $9.63 ; \mathrm{p}=$ 0.003).

\section{DISCUSSION}

From the multiple regression analysis of the present study, it was indicated that all of the dependent variables investigated in this study i.e. age at menarche, age at menopause, age at first pregnancy, and use of hormonal contraceptive, were associated with the risk of breast cancer.

\section{The association between age at menarche and breast cancer}

Menarche marks the onset of ovarian activity associated with reproduction, and affect breast cancer risk. During women's reproductive years (broadly the time between menarche and menopause) the ovary produces steroid hormones that directly affect development and function of the breast. Early menarche and late menopause are known to increase women's risk of developing breast cancer (Collaborative Group on Hormonal Factors in Breast Cancer, 2012).

The present study found that age at menarche had a significant relationship with breast cancer in women. The result of the multivariate analysis shows that age at menarche $<12$ years increased the risk of breast cancer $(\mathrm{OR}=2.71 ; 95 \% \mathrm{CI}=1.06$ to 6.96; $\mathrm{p}=0.037$ ).
This result is consistent with Li et al., (2017) which stated that age at menarche had a significant relationship with the incidence of breast cancer.

This study is also consistent with a meta-analysis, which reported that breast cancer risk increased by a factor of 1.05 (95\% CI $=1.04-1.06 ; \mathrm{p}<0.001$ ) for every year younger at menarche (Collaborative Group on Hormonal Factors in Breast Cancer, 2012).

Too early menarche, which is less than 12 years, causes early exposure to estrogen hormone. In turn, the increased estrogen hormone causes the abnormal growth of cells. Breast cancer can occur due to estrogen stimulation of epithelial cell division. Estrogen with its metabolites directly acts as a mutagen, which results in the emergence of cancer cells (Hamajima et al., 2012).

Conversely, the estrogen hormone prevents heart attack and protects bones. Insufficient estrogen hormone at a young age increases a woman's risk for heart or bone disorders (Ewaid and Al-Azzawi, 2016).

This result is consistent with Ewaid and Al-Azzawi studies (2016) which reported that early menstrual period $<12$ years were associated with an increased risk of breast cancer. Conversely, age menarche $\geq 17$ years were associated with a decreased risk of breast cancer by $30 \%$.

\section{The association between age at first pregnancy and the risk of breast cancer}

This study found that age at first pregnancy was a strong risk factor of breast cancer. Women with age at first pregnancy $\geq 30$ years were more likely to get breast cancer than age at menarche $<30$ years.

The fact that reproductive factors have significant influence on the risk of breast cancer is well known. Early age of 
first full-term birth is highly protective against late-onset breast cancers, but each pregnancy, including the first one, increases the risk of early-onset breast cancer (Kobayashi et al., 2012).

This is possible because at the firsttrimester pregnancy the estrogen hormone level is high, resulting in the process of cell multiplication through rapid mitosis that causes cancer cell division (Becker, 2015; Goldberg et al., 2015; Morales et al., 2013).

This study is consistent with the study of Mockus et al. (2015) which states that the increased risk for breast cancer is associated with increased age at first pregnancy.

Delay of first birth together with low parity and short duration of breast feeding are increasing social trends in developed countries. Therefore, breast cancer risk as a result of reproductive factors will not decrease in these countries in the foreseeable future (Kobayashi et al., 2012).

\section{The association between age at menopause and the risk of breast cancer}

Menopause marks the cessation of ovarian activity associated with reproduction, and affect breast cancer risk (Collaborative Group on Hormonal Factors in Breast Cancer, 2012).

The present study found that age at menopause <55 years was a weak risk factor of breast cancer. Women with age at menopause $<55$ years were more likely to get breast cancer than age at menopause $\geq 55$ years.

Women who experience menopause at older ages have longer exposure of estrogen hormone in the blood, which will result in an increased risk of breast cancer (Bakht and Najafi, 2010; Mahmoud et al., 2015; Nagrani et al., 2016).

The period between first menstrual occurrence and age at first pregnancy is a window of initiation of breast cancer development. Anatomically and functionally, the breasts will experience atrophy according to age. Less than $25 \%$ of breast cancers occur prior to menopause (Becker, 2015, Morales et al., 2013). Women with menopause at age 55 or older have a 50\% higher risk of breast cancer than less than 55 years. Similarly, women with menopause less than 45 years have a 30\% higher risk of breast cancer than over 45 years (Mockus et al., 2015).

The main risk of breast cancer is the increasing age of the individual. The longer a person lives, the higher the risk of cancer because of the physical condition decreases and easily becomes abnormal (Laamiri et al., 2015; Mahmoud et al., 2015; Nagrani et al., 2016).

As discussed above, prior studies indicate that women with menopausal symptoms have lower estrogen levels because they go through menopause as compared with women who do not experience them. Given the central role of hormones in the etiology of breast cancer, a link between menopausal symptoms and breast cancer is plausible.

Huang et al. (2011) went further to evaluate the association between menopausal symptoms and breast cancer risk. The authors found that women who ever experienced menopausal symptoms had lower risks of invasive ductal carcinoma (IDC) $(\mathrm{OR}=0.5 ; 95 \% \mathrm{CI}: 0.3-0.7)$, invasive lobular carcinoma (ILC) $(\mathrm{OR}=0.5$; 95\% CI: 0.3-0.8), and invasive ductal-lobular carcinoma (IDLC) $(\mathrm{OR}=0.7$; 95\% CI: 0.41.2). These reductions in risk were independent of recency and timing of hormone therapy use, age at menopause, and body mass index. Increasing intensity of hot flushes among women who ever experienced hot flushes was also associated with decreasing risks of all three breast 
Journal of Epidemiology and Public Health (2018), 3(2): 118-127

https://doi.org/10.26911/jepublichealth.2018.03.02.02

cancer subtypes ( $\mathrm{P}$ values for trend all $\leq$ 0.017). Huang et al. (2011) concludes that women who ever experienced menopausal symptoms have a substantially reduced risk of breast cancer, and that severity of hot flushes is also inversely associated with risk.

\section{The association between use of contraceptive and the risk of breast cancer}

This study found that the longer using hormonal contraceptives will provide increased risk of breast cancer. Women who use hormonal contraceptives $<10$ years are at lower risk than women who never use hormonal contraceptives.

The result of the present study is consistent with a prospective cohort study by Kumle et al. (2002), which was specifically designed to examine the role of hormonal contraceptives in relation to breast cancer was conducted in Norway and Sweden. This study was entitled Women's Lifestyle and Health. Of 196,000 invited women aged 30-49 years, 106,844 women answered a 4-page questionnaire. Altogether, 103,027 women providing information on contraceptive use were included in the analysis, and 1,008 primary invasive breast cancers were diagnosed throughout 1999 (end of follow-up). The author used proportional hazard regression model to calculate relative risks (RRs) with adjustment for age and other possible confounders. An increased breast cancer risk was observed among women who were recent users of oral contraceptives (OCs) of any type at the start of follow-up $(R R=1.6$; 95\% CI=1.2-2.1).

The loss of the cellular function of the programmed cell (apoptosis) will lead to the inability to detect the presence or absence of cell damage resulting from damage to DNA, so that abnormal cells will continue to be uncontrollably polymerized
(Mahmoud et al., 2015; Nakamura et al. , 2017).

The result of this study is consistent with the study conducted by Youlden et al. (2014), which stated that there was a significant relationship between the hormonal contraceptives use and the risk of breast cancer.

Devi (2011) stated that women who consumed combined contraceptive pill had a risk of 1.86 times for breast cancer than those with the non-combined contraceptive method. The duration of combined contraceptive method use in the case group was highest in the 5-9 year of age group (Oktaviana, 2011).

$\mathrm{Li}$ et al. (2017b) conducted a metaanalysis to investigate the association between oral contraceptive use as a risk factor and triple-negative breast cancer. The study indicated that women who used OCs had a greater risk of TNBC compared with women who did not. This conclusion prompts that women who used OCs should be examined more closely in population screenings of breast cancer, as they may benefit from prevention and early detection strategies.

The association between oral contraceptive use and risk of breast cancer was also evident by histologic type of the breast cancer. Newcomer et al. (2003) examined the association between oral contraceptive use and risk of specific breast cancer histopathologies in a large, multicenter, population-based, case-control study. Women younger than age 75 with a new diagnosis of invasive breast cancer were identified from 4 statewide tumor registries. The authors compared women with lobular $(n=493)$ and ductal carcinoma $(\mathrm{n}=5,510)$ to randomly selected controls $(\mathrm{n}=9,311)$. Odds ratios (OR) and 95\% confidence intervals (CI) for each histologic type were estimated using polytomous 
logistic regression, adjusted for other breast cancer risk factors. Current oral contraceptive use was associated with increased risk of lobular carcinoma $(\mathrm{OR}=2.6,95 \%$ $\mathrm{CI}=1.0$ to 7.1 ) and there was a significant trend $(\mathrm{p}=0.017)$ of increased risk with more recent use. Oral contraceptive use was not clearly associated with ductal carcinoma $(\mathrm{OR}=1.2,95 \% \mathrm{CI}=0.8$ to 1.9$)$. These results suggest that the association between oral contraceptive use and risk of breast cancer may vary by histologic type.

The present study concludes that the risk of breast cancer increases with earlier age at menarche, delayed age at first pregnancy, delayed age at menopause, and longer hormonal contraceptive use.

$\frac{\text { REFERENCE }}{\text { Bakht S, Najafi S (2010). Body image and }}$ sexual dysfunctions: Comparison between breast cancer patients and healthy women. Procedia - Social and Behavioral Sciences, 5(2): 1493-1497. https://doi.org/10.1016/j.sbspro.201 0.07.314.

Becker S (2015). International Journal of Gynecology and Obstetrics Reproductive Healtha historic and scientific review of breast cancer: The next global healthcare challenge. International Journal of Gynecology and Obstetrics, 131, S36-S39. https://doi.org/10.1016/j.ijgo.2015.03.015

Collaborative Group on Hormonal Factors in Breast Cancer (2012). Menarche, menopause, and breast cancer risk: individual participant meta-analysis, including 118964 women with breast cancer from 117 epidemiological studies. Lancet Oncol. 13(11): 11411151. doi: 10.1016/S1470-2045(12)70425-4.

Di Sibio A, Abriata G, Forman D, Sierra MS (2016). Female breast cancer in Cen- tral and South America. Cancer Epidemiology, 44, S110-S120. https://doi.org/10.1016/j.canep.2016.08.010.

Ewaid SH, Al-Azzawi LHA (2016). Breast cancer risk assessment by Gail Model in women of Baghdad. Alexandria Journal of Medicine, https://doi.org/10.1016/j.ajme.2016.09.001.

Goldberg M, Calderon-Margalit R, Paltiel $\mathrm{O}$, Abu Ahmad W, Friedlander Y, Harlap S, Manor O (2015). Socioeconomic disparities in breast cancer incidence and survival among parous women: findings from a populationbased cohort, 1964-2008. BMC Cancer, 15(1): 921. https://doi.org/10.1186/s12885-015-1931-4.

Graham K, Hakam Y, Kaza N, Mikhail M, Doherty R M, Tasker R, Von der Muhill V (2016). World cancer declaration: Progress report 2016. Union for International Cancer Control, 1156. Retrieved from http://www.uicc.org/sites/main/files/atoms/files/UICC_WorldCancerDeclaration_Prog ress_Report_2016_Book.pdf.

Hamajima N, Hirose K, Tajima K, Rohan T, Friedenreich CM, Calle EE, Fukao A (2012). Menarche, menopause, and breast cancer risk: Individual participant meta-analysis, including 118 964 women with breast cancer from 117 epidemiological studies. The Lancet Oncology, 13(11), 1141-1151. https://doi.org/10.1016/S1470-2045(12): 70425-4.

Huang Y, Malone KE, Cushing-Haugen KL, Daling JR, Li CI (2011). Relationship between menopausal symptoms and risk of postmenopausal breast cancer. Cancer Epidemiol Biomarkers Prev. 20(2):379-88. doi: 10.1158/1055-9965.EPI-10-0998.

Leon RT, Novotny R, Wilkens LR, Chong M, Blas-laguana M (2017). Risk 
Journal of Epidemiology and Public Health (2018), 3(2): 118-127

https://doi.org/10.26911/jepublichealth.2018.03.02.02

factors for breast cancer in the breast cancer risk model study of Guam and Saipan. Cancer Epidemiology, 50, 221-233. https://doi.org/10.1016/j.canep.2017.04.008.

Kementerian Kesehatan RI Pusat Data dan Informasi Kesehatan (2016). Bulan Peduli Kanker Payudara. InfoDATIN. https://doi.org/ISSN 2442-7659

Kementerian Kesehatan RI Pusat Data dan Informasi Kesehatan (2015). Stop Kanker. Infodatin-Kanker, hal 3.

Kobayashi S, Sugiura H, Ando Y, Shiraki N, Yanagi T, Yamashita H, Toyama $\mathrm{T}$ (2012). Reproductive history and breast cancer risk. Breast Cancer. 19(4): 302-308.

Kumle $\mathrm{M}$, Weiderpass $\mathrm{E}$, Braaten $\mathrm{T}$, Persson I, Adami HO, Lund E (2002). Use of Oral Contraceptives and Breast Cancer Risk. The Norwegian-Swedish Women's Lifestyle and Health Cohort Study. Cancer Epidemiology, Biomarkers \& Prevention. 11(11): 13751381.

Kweon SS, Kim MG, Kang MR, Shin MH, Choi JS (2017). Difference of stage at cancer diagnosis by socioeconomic status for four target cancers of the National Cancer Screening Program in Korea: Results from the Gwangju and Jeonnam cancer registries. Journal of Epidemiology, 27(7), 299304. https://doi.org/10.1016/j.je.2016.07.004.

Laamiri F Z, Bouayad A, Hasswane N, Ahid $S$ (2015). Risk Factors for Breast Cancer of Different Age Groups: Moroccan Data? Journal of Obstetrics and Gynecology, 5(February), 79-87.

Li H, Sun X, Miller E, Wang Q, Tao P, Liu L, Li J (2017). BMI, reproductive factors, and breast cancer molecular subtypes: A case-control study and metaanalysis. Journal of Epidemiology,
27(4): 143-151. https://doi.org/10.1016/j.je.2016.05.002.

Li L, Zhong Y, Zhang H, Yu H, Huang Y, Li Z, Chen G, Hua X (2017b). Association between oral contraceptive use as a risk factor and triple-negative breast cancer: A systematic review and meta-analysis. Mol Clin Oncol. 7(1):76-80. doi: 10.3892/mco.2017.1259.

Lukong KE (2017). Understanding breast cancer - The long and winding road. BBA Clinical, 7: 64-77. https://doi.org/10.1016/j.bbacli.2017.01.001.

Mahmoud AS, Abdulrahman MA, Bakheit $\mathrm{KH}$ (2015). Science Direct Insulin, estradiol levels and body mass index in pre- and post-menopausal women with breast cancer. Journal of Radiation Research and Applied Sciences, 8(4), 617-620. https://doi.org/10.1016/j.jrras.2015.07.004.

Mockus M, Prebil L, Ereman R, Dollbaum C, Powell M, Yau C, Benz CC (2015). First pregnancy characteristics, postmenopausal breast density, and Salivary sex hormon levels in a population at high risk for breast cancer. BBA Clinical, 3, 189-195.

Morales L, Alvarez-Garriga C, Matta J, Ortiz C, Vergne Y, Vargas W, Bayona $M$ (2013). Factors associated with breast cancer in Puerto Rican women. Journal of Epidemiology and Global Health, 3(4), 205-215. https://doi.org/10.1016/j.jegh.2013.08.003.

Nagrani R, Mhatre S, Rajaraman P, Soerjomataram I, Boffetta P, Gupta S, Dikshit R (2016). Central obesity increases risk of breast cancer irrespective of menopausal and hormonal receptor status in women of South Asian Ethnicity. European Journal of Cancer, 66, 153-161. https://doi.org/10.1016/j.ejca.2016.07.022. 
Nakamura K, Okada E, Ukawa S, Hirata M, Nagai A, Yamagata Z, Nakagawa T (2017). Characteristics and prognosis of Japanese female breast cancer patients: The BioBank Japan project. Journal of Epidemiology, 27, S98S106.https://doi.org/10.1016/j.je.201 6.12.012.

Newcomer LM, Newcomb PA, Dietz AT, Longnecker MP, Greenberg ER (2003). Oral contraceptive use and risk of breast cancer by Histologic type. Int. J. Cancer. 106: 961-964.

Oktaviana DN (2011). Di Rumah Sakit Kanker Dharmais Jakarta.

World Health Organization (2014). Cancer Country Profiles: Indonesia. Cancer Country Profiles, 22-23.

Youlden D R, Cramb S M, Yip C H, Baade P $D$ (2014). Incidence and Mortality of Female Breast Cancer in the AsiaPacific Region. Cancer Biology \& Medicine, 11(2), 101-15. 